Apostolos Kaltsas, 2021

Volume 5 Issue 3, pp. 37-52

Received: $2^{\text {nd }}$ April 2021

Revised: 18 $8^{\text {th }}$ October 2021, $2^{\text {nd }}$ December 2021

Accepted: 16 th December 2021

Date of Publication: 17th December 2021

DOI- https://doi.org/10.20319/pijtel.2021.53.3752

This paper can be cited as: Kaltsas, A. (2021). Mental Resilience in Education: The Case of Greek High Schools Teachers. PUPIL: International Journal of Teaching, Education and Learning, 5(3), 37-52.

This work is licensed under the CreativeCommons Attribution-NonCommercial 4.0 International License. To view a copy of this license, visit http://creativecommons.org/licenses/by-nc/4.0/ or send a letter to Creative Commons, PO Box 1866, Mountain View, CA 94042, USA.

\title{
MENTAL RESILIENCE IN EDUCATION: THE CASE OF GREEK HIGH SCHOOLS TEACHERS
}

\author{
Apostolos Kaltsas \\ Secondary Education of Piraeus, 1st Ergastiriako Kentro (E.K.) of Piraeus, Greece \\ apkalt@yahoo.co.uk
}

\begin{abstract}
The term "mental resilience" defines the ability of the individual to overcome any adversity and to continue to develop. It is part of the set of personality traits, as well as genetic traits with which a person is either born or acquired in infancy and/or childhood. Teachers play an important role in promoting students' mental health in creating a suitable and supportive environment for them, since with their support students can acquire skills that will enhance their self-image and self-confidence, thus helping them in their evolution and progress. This paper aims to investigate the mental resilience of high school teachers and how it correlates with gender, age, and years of service. The survey involved 29 teachers (18 men (62.1\%) and 11 women (37.9\%)) who served in high schools in the prefecture of Attica in Greece. The ConnorDavidson Resilience Scale (CD-RISC) was used to measure mental resilience. This questionnaire consists of 25 self-rated items with a 5-point scale from 0 ('not true at all') to 4 ('true nearly all the time') which correspond to five factors. The analysis of the results showed that the participants had high resilience, gender is correlated with "trust in one's instincts" factor
\end{abstract}


positively and statistically significant, years of service correlated with "control" factor positively and statistically significant, and with "personal tolerance" factor negatively and statistically significant. Age was found to be positive and statistically significantly correlated with the "control" factor. In conclusion, in the era of continuous development and change, mental resilience is important for the field of education as teachers play an important role in the lives of children facing difficulties while contributing to the promotion of collaborative school culture.

\section{Keywords}

Mental Resilience, Teachers, Promotion of Mental Resilience

\section{Introduction}

Mental resilience is generally defined as an individual's ability to adapt positively to traumatic experiences (Masten, 2001). Mental resilience as a human ability can overcome and transform the adversities of one's life and is not a permanent feature. Furthermore, it is not a onedimensional property but arises through the interaction of risk factors and protective factors of the individuals and their protective environment (Masten \& Curtis, 2000). Mental resilience is described as a characteristic of people that exists potentially in each individual and develops through an ever-evolving process. It is a part of a set of genetic traits as well as personality traits with which either the person is born or acquires them in infancy or childhood (Linde-Leimer \& Wenzel, 2014). It can also be characterized as a dynamic process within a social system of interactions (Higgins, 1994; Bernard, 1995) and defined as the ability to adapt positively to adversity (Luthar, Cicchetti \& Becker, 2000). Well-being and resilience are important in preventing and reducing the severity of mental health problems (Fenwick-Smith, Dahlberg \& Thompson, 2018). Moreover, mental resilience is influenced by one's sense of control over one's life, one's ability to accept support and help, one's sense of hope and hobbies, and creativity (Tusaie \& Dyer, 2004; Rutter, 2012; Hornor, 2004).

Moreover, personal characteristics, skills, and positive influences of the social environment contribute to the building of mental resilience (Gordon \& Song, 1994; Rutter 2012; Zucker, 2006). It is often described as a catastrophe, a conflict, or a confrontation, It is also described as an event that disrupts the normal progression of a person's life, resulting in a possible activation of one's resilience mechanisms (Chmitorz et al., 2018; Spyropoulos, 2018). 
In today's modern society where changes in interpersonal relationships in the workplace are evident, adolescents are likely to be at school without significant help when facing adversity.

It should be noted that school is one of the most important factors that can create the right environment and conditions that promote the mental resilience of adolescents (Hederson \& Milstein, 2008).

In addition to mental resilience, the school environment can affect students' self-esteem, self-image, and expectations. Segal (1988) argues that the presence of an adult with whom they can identify and by whom they can be supported plays an important role in the lives of children who are not resilient. According to O'Reilly, Svirydzenka \& Adams (2018) actions that facilitate an environment that respects and protects basic civil, political, socio-economic, and cultural rights at school are fundamental to mental health promotion.

Teachers should equip students with the skills they need to meet the growing challenges of the future. With this support, the students can acquire the skills that will help them to strengthen their self-image and self-confidence that will help them in their development and progress (Cefai, 2011). Taking all the above factors into account we shall try to investigate the mental resilience of Greek high school teachers and how it correlates with gender, age, and years of service as this important issue has a direct impact on the quality of education provided.

\section{Conceptual Framework}

With this analytical tool we can get a comprehensive understanding and explain the following key concepts:

\subsection{The Mental Resilience of Adolescents}

Adolescents' mental resilience differs from that of adults concerning exposure to stressful events and risks. As for adults, it refers to dealing with a stressful event and returning to normalcy after exposure to it, while in adolescents it refers to preventing their involvement in delinquent habits and strengthening their character (Fergus and Zimmerman, 2005).

Interventions at this critical age are important because they can lead to the prevention of psychosocial difficulties and the improvement of the general health of the adult population of tomorrow. These interventions can be enhanced by the influence of external supportive factors such as a stable relationship with an emotionally stable adult such as a teacher can offset the negative effects of students' traumatic experiences (Fergusson \& Horwood, 2003). 
In addition, the support of adolescents in early childhood can offset the effects of difficult parental care or any difficult socioeconomic conditions they may experience. (Fergus and Zimmerman, 2005).

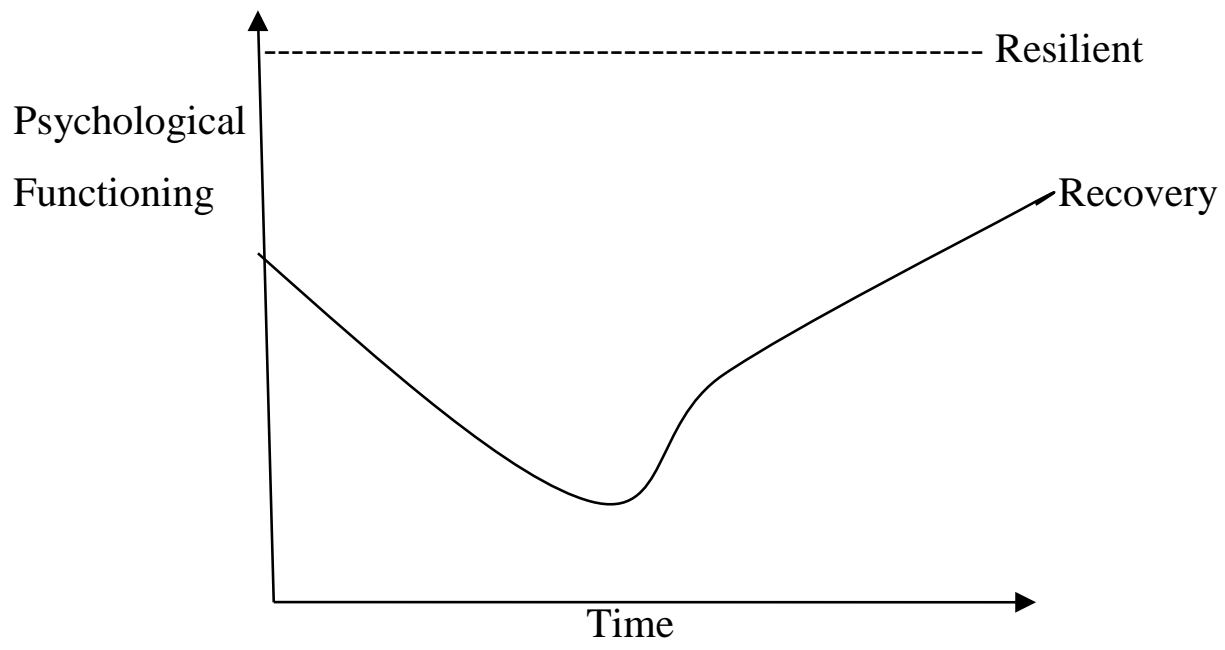

Figure 1: Possible Response Patterns in Adults Following Adversity

(Source: Medical xpress https://medicalxpress.com/news/2018-08-youre-re-evaluates-resilienceadults.html)

\subsection{Mental Resilience at School}

School is the right place not only for the development of mental resilience but also for all the skills that are necessary for the smooth development of the adolescent. Owing to the wide recognition of academic resilience as a key factor in determining students' success or failure, the 21 st-century society requires that schools and teachers should enhance the resilience of young people (Mwangi et al, 2018). The promotion of mental resilience in the context of the school environment facilitates both the learning process and the adaptation of students to the school and the wider social environment.

In addition, the mental resilience of adults working in schools is important, because not only do they play an important role in the mental resilience of schools, but they also act like adults who protect the lives of children in difficulty. By creating warm personal relationships, schools can serve to promote mental resilience better than any other community. The conditions for achieving this goal are the appropriate organization of the school structure, teaching methods, courses, and of course the contribution of teachers themselves (Chadzichristou, 2011). 


\subsection{The Role of Teachers}

The influence of teachers on the socio-emotional development of adolescent students is important as they have frequent contact and can more easily detect changes in their moods. They must be distinguished by mental resilience to be able to respond successfully to their duties. Furthermore, they should realize that in addition to the cognitive level, the mental health of students is important as well as the prevention of problematic behaviors (Chadzichristou, 2011). Regarding the personality traits of teachers, it should be emphasized that it is crucial for the relationships they develop with their students. They also should be distinguished by a willingness to offer and have communication skills, a good mood, patience, enthusiasm.

Finally, they should be able to create an atmosphere that facilitates the expression of emotions and find ways to arouse the interest of students, and most importantly to have empathy and social awareness (Maridaki-Kassotaki, 2013).

\subsection{Obstacles in the Process of Promoting Mental Resilience at School}

The time constraints that exist in the school curriculum are an important factor that hinders the process of promoting mental resilience in school. Also, the stereotypes that teachers should be limited only to their teaching work and that students should be engaged only in gaining the necessary knowledge they need act as inhibitors in the promotion of mental resilience in the school environment (Henderson \& Milstein, 2008).

In addition, the disorganization and large size of the school is another important deterrent as it is quite difficult to develop strong bonds and a more intimate atmosphere among members of the school community. This results in the difficulty of applying rules concerning the desired behavior as well as appropriate teaching strategies that will promote mental resilience. It should be emphasized that the lack of prevention and intervention programs observed in secondary education is perhaps the most important obstacle to promoting mental resilience in the school environment (Henderson \& Milstein, 2008).

Finally, the factors that hinder the intervention of teachers are the insufficient state support, the insufficient material and technical infrastructure of the schools, the lack of proper training, the conditions for their teaching work as well as the possible excessive demands from the administration and the parents. 


\subsection{Factors that Contribute to the Increase of Mental Resilience at School}

Mental resilience in secondary schools according to Ginsburg \& Jablow (2014) could be increased if adolescents acquired confidence, close family ties, effective coping skills, a sense of well-being, and control of their decisions. Some factors could enhance the intervention of teachers such as their participation in defining the "vision" of the school, the creation of a sense of belonging to it, the emotional and psychological support from colleagues, their professional development, their training, the ability to take initiatives and innovative actions as well as the reward of their efforts (Henderson \& Milstein, 2008).

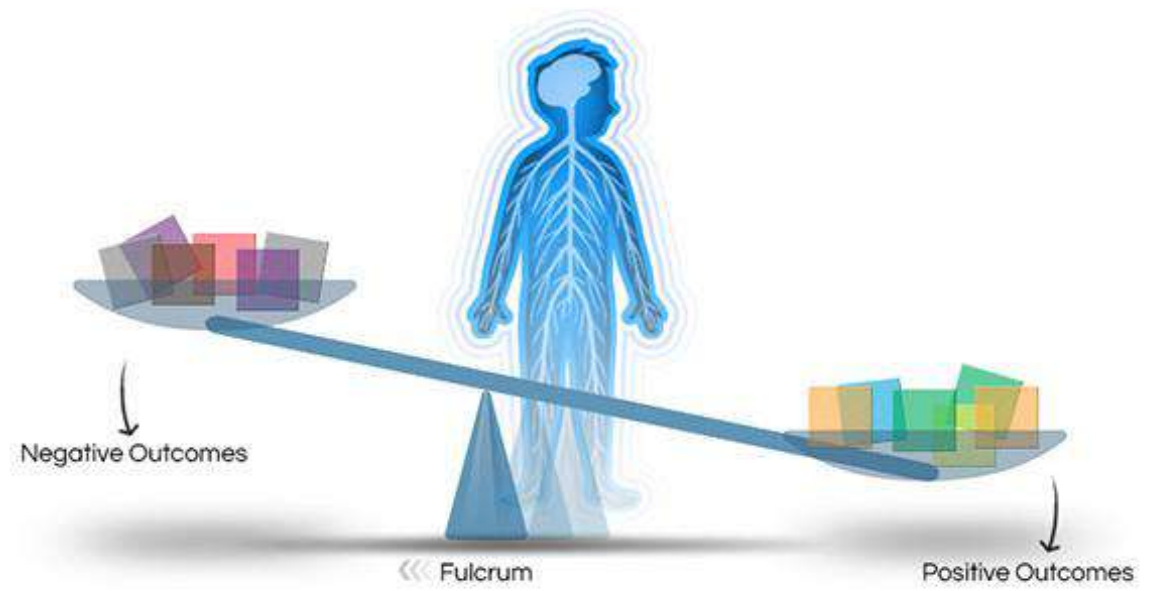

Figure 2: A Balance Scale of Resilience

(Source: Harvard University https://developingchild.harvard.edu/science/keyconcepts/resilience/ )

\section{Methodology}

The specific procedures and techniques used to identify and analyze the research topic were as follows:

\subsection{Purpose of the Research}

The role of teachers is important in promoting mental resilience at school (Krovetz, 1999). The mental resilience of teachers is determined by their working conditions and the possibilities for their professional development. This paper aims to investigate the mental resilience of Greek high school teachers and the correlation of mental resilience with gender, age, and years of service. The research questions that our research aims to answer are the following: 
- Have the teachers of the examined sample had high rates of mental resilience?

- Do the years of service correlate with mental resilience?

- Does the gender of teachers correlate with mental resilience?

- Does the age of teachers correlate with mental resilience?

\subsection{The Research Sample}

The research was conducted in high schools in Attica in Greece. 29 teachers participated (18 men (62.1\%) and 11 women (37.9\%)). $10.3 \%$ of these were aged 35 and younger, $31 \%$ were aged 35-44, 27.6\% were aged 45-54, 20.7\% were aged 55-64, and 10.3\% were aged 64 or over. As regards the years of service 17,2\% had less than 10 years, 41,4\% had 10-20 years, 24,1\% had 20-30 years, while $17,2 \%$ had more than 30 .

Table 1: Gender of the Sample

\begin{tabular}{|c|c|c|c|c|}
\hline \multirow{3}{*}{ Gender } & & $\begin{array}{l}\text { Frequency } \\
(\mathrm{N})\end{array}$ & $\begin{array}{l}\text { Percent } \\
(\%)\end{array}$ & $\begin{array}{l}\text { Cumulative } \\
\text { percent } \\
(\%)\end{array}$ \\
\hline & Men & 18 & 62,1 & 62,1 \\
\hline & Women & 11 & 37,9 & 100,0 \\
\hline Total & & 29 & 100,0 & \\
\hline
\end{tabular}

(Source: Self)

Table 2: Age of the Sample

\begin{tabular}{|l|l|l|c|c|}
\hline \multicolumn{2}{|c|}{} & Frequency (N) & Percent (\%) & $\begin{array}{c}\text { Cumulative } \\
\text { Percent (\%) }\end{array}$ \\
\hline \multirow{4}{*}{ Age } & Less than 35 & 3 & 10,3 & 10,3 \\
\cline { 2 - 5 } & $35-44$ & 9 & 31,0 & 41,4 \\
\cline { 2 - 6 } & $45-54$ & 8 & 27,6 & 69,0 \\
\cline { 2 - 6 } & $55-64$ & 6 & 20,7 & 89,7 \\
\cline { 2 - 6 } & More than 64 & 3 & 10,3 & 100,0 \\
\hline Total & & $\mathbf{2 9}$ & $\mathbf{1 0 0 , 0}$ & \\
\hline
\end{tabular}

(Source: Self) 
Table 3: Years of Service of the Sample

\begin{tabular}{|c|c|c|c|c|}
\hline & & Frequency $(\mathbf{N})$ & Percent (\%) & $\begin{array}{c}\text { Cumulative percent } \\
(\%)\end{array}$ \\
\hline \multirow[t]{4}{*}{ Years of service } & $\begin{array}{c}\text { Less than } \\
10\end{array}$ & 5 & 17,2 & 17,2 \\
\hline & $10-20$ & 12 & 41,4 & 58,6 \\
\hline & $20-30$ & 7 & 24,1 & 82,8 \\
\hline & $\begin{array}{c}\text { More than } \\
30\end{array}$ & 5 & 17,2 & 100,0 \\
\hline \multicolumn{2}{|l|}{ Total } & 29 & 100,0 & \\
\hline
\end{tabular}

(Source: Self)

\subsection{The Research Tool}

In the present research, the Connor-Davidson Resilience Scale (CD-RISC) (Connor \& Davidson, 2003) was used to measure mental resilience.

The (CD-RISC) questionnaire consists of 25 self-report statements that are weighed on a five-point scale where: 0 - Not at all true, 1 - Rarely true, 2 - Sometimes true, 3 - Often true, 4 Almost always true), in this way the mental resilience of an individual is assessed. The range of results ranges from 0 to 100, where higher scores mean greater mental resilience. These self-report statements correspond to the following factors:

- "Individual competence, high criteria and persistence" with 8 statements (statements: 10, 11 ,

$12,16,17,23,24,25$ of the questionnaire).

- "Belief in personal instinct, leniency/tolerance for negative mood and the empowering effect of stress" with 7 statements (statements $6,7,14,15,18,19,20$ of the questionnaire).

- "Positive acceptance for changes and secure relationships" with 5 statements (statements 1, $2,4,5,8$ of the questionnaire)

- "The control" with 3 statements (statements 13,21, and 22 of the questionnaire).

- "Intellectual effects", with 2 statements (statements 3 and 9 of the questionnaire).

The rating is based on how the survey participants have felt during the last 30 days. This scale has been used in adults, in the general population, and also clinical cases, with satisfactory validity, good internal coherence, and reliability of control. The score of each factor is calculated 
from the sum of the statements of each factor. The total score of the CD-RISC is calculated from the sum of the answers to the 25 questions (Connor \& Davidson, 2003).

\subsection{Statistical Data Analysis}

The statistical processing of the questionnaires and the analysis of the results was carried out with the program Statistical Package for the Social Sciences-SPSS 22. For the correlations between the variables, the Pearson correlation coefficient was used. For all cases the value of $p$ (Asymp. Sig) p <0.05 was calculated to determine whether the differences were significant.

\section{Results}

The analysis of the results showed that the participants had high resilience; gender is correlated with the "trust in one's instincts" factor positively and statistically significant; years of service correlated with "control" factor positively and statistically significant and with "personal tolerance" factor negatively and statistically significant. Age was found to be positive and statistically significantly correlated with the "control" factor. The whole mental resistance of our sample was found 76.06 which means a high rate.

Table 4: Descriptive Statistics of the Dimensions of the CD-RISC

\begin{tabular}{|l|r|l|l|l|l|}
\hline & $\mathbf{N}$ & Minimum & Maximum & Mean & S.D. \\
\hline Personal tolerance & 29 & 22 & 33 & 26,90 & 2,782 \\
\hline Trust in one's instinct & 29 & 15 & 26 & 19,17 & 2,726 \\
\hline Positive acceptance of change & 29 & 13 & 22 & 16,41 & 2,260 \\
\hline Control & 29 & 8 & 12 & 10,07 & 1,223 \\
\hline Spiritual influences & 29 & 3 & 8 & 5,59 & 1,524 \\
\hline Valid N (listwise) & $\mathbf{2 9}$ & & & & \\
\hline
\end{tabular}

(Source: Self)

From the above table, we conclude that the mean of "spiritual influences" is lower (5.59), while the individual dimension of "personal tolerance" has a higher mean than all dimensions (26.90). Therefore, "personal tolerance" has a greater effect on mental resilience while "spiritual influences" have the least degree of influence on mental resilience of all the dimensions of the 
CD-RISC. The correlations of the dimensions of CD-RISC show that gender is correlated only with "trust in one's instincts", years of service are correlated only with "control" and with "personal tolerance" factors, and age is correlated only with the "control" factor $(\mathrm{p}<0.05)$.

Table 5: Correlations of the Dimensions of the CD-RISC

\begin{tabular}{|c|c|c|c|c|c|c|c|c|}
\hline & Gender & Age & $\begin{array}{c}\text { Years } \\
\text { of } \\
\text { service }\end{array}$ & $\begin{array}{l}\text { Personal } \\
\text { tolerance }\end{array}$ & $\begin{array}{l}\text { Trust } \\
\text { in } \\
\text { one's } \\
\text { instinct }\end{array}$ & $\begin{array}{c}\text { Positive } \\
\text { acceptance } \\
\text { of } \\
\text { change }\end{array}$ & Control & $\begin{array}{l}\text { Spiritual } \\
\text { influences }\end{array}$ \\
\hline Gender & - & & & & & & & \\
\hline Age & 0.008 & - & & & & & & \\
\hline $\begin{array}{l}\text { Years of } \\
\text { service }\end{array}$ & 0,107 & 0,904 & - & & & & & \\
\hline $\begin{array}{l}\text { Personal } \\
\text { tolerance }\end{array}$ & $-0,230$ & 0,095 & $-0,010$ & - & & & & \\
\hline $\begin{array}{l}\text { Trust in } \\
\text { one's } \\
\text { instict }\end{array}$ & 0,003 & $-0,395$ & $-0,201$ & 0,125 & - & & & \\
\hline $\begin{array}{l}\text { Positive } \\
\text { acceptance } \\
\text { of change }\end{array}$ & 0,334 & $-0,158$ & $-0,091$ & 0,098 & 0.150 & - & & \\
\hline Control & 0,133 & 0,005 & 0,005 & 0,485 & 0,146 & 0,183 & - & \\
\hline $\begin{array}{l}\text { Spiritual } \\
\text { influences }\end{array}$ & 0,704 & 0,095 & 0,262 & 0,251 & 0,155 & 0,166 & 0,246 & - \\
\hline
\end{tabular}

(Source: Self)

\section{Discussion}

The reasons why mental resilience is important in the field of education were reported in the theoretical part of the paper. If there is an educational environment at school that favors the development of mental resilience, students overcome their difficulties more easily and progress (Bernard, 2004; Johnson, 2008). The sample of research teachers was found to have significantly high rates of mental resilience as the results showed. Mental resistance was measured with Connor-Davidson Resilience Scale (CD-RISC) and the sum of all responses gave a total score. 
The teachers of our sample may have self-efficacy, as well as a sense of success and be proud of their achievements. In addition, they may have flexibility, adaptability and generally feel very well with their work. The results of our research are in line with the results of research carried out by Siourla (2018) who found that the mental resistance of teachers was highly rated. As regards age several studies have shown that resilience does not decline with age and older adults are at least as resilient as younger adults (Nygren et al, 2005; Gooding et al, 2012). In our research was found to be positive and statistically significantly correlated only with the "control" factor. In a survey carried out in 2007 by Lundman, Strandberg, Eisemann, Gustafson, and Brulin in Sweden was found that the older were the participants, the more resilient they were presented. Variable results have been found linking resilience to gender. Some studies (Hardy et al, 2004; Seidel et al, 2009) have found men to be more resilient in older age while at least one study (Netuveli et al, 2008) found women to be more resilient. In our research was found to be correlated positively and statistically significant only with the "trust in one's instincts" factor.

In addition, the years of service of teachers affected the mental resistance since according to the results of our research years of service correlated with the "control" factor positively and statistically significant and with the "personal tolerance" factor negatively and statistically significant. This is likely due to high levels of stress, exhaustion, and the requirements of teaching experienced by teachers (Jalongo \& Heider, 2006). Recent studies also showed that special education teachers have been under high occupational pressure and that close relationships existed between their mental and physical health (Zhang, Bai \& Li, 2020). In research by Pearce and Morrison (2011) was found that teachers who were at the beginning of their career had lower mental resistance as they were trying to form their professional identity while Day and Gu (2013) argue that teachers with a few years of service have more chances to maintain the sense of mental resistance concerning those with several years of service. According to them, this is why mental resilience is reduced due to changes made by governments, pupils' behavior, and workload. They also argue that the deterioration of teachers' health is an important factor in reducing their mental resilience. In summary, we should highlight that the mental resilience of teachers is a complex and multidimensional phenomenon that plays an important role in their life and work and at the same time is one of the main factors in students' success. 


\section{Conclusion}

The process of promoting mental resilience is a matter of growing importance to students and teachers as a result of increasing the unaccountable situations facing people in their everyday lives. Interventions in the school environment should include as a primary goal the promotion of mental resilience and well-being of teachers by providing them with appropriate guidance and support as the school environment is one of the main factors that contribute to the development process and shaping of the student's identity (Theodosakis, 2011).

It is also important for school principals to be able to create the right conditions to support teachers' mental resilience. Factors that could contribute $\tau$ o this direction are trust and honesty towards teachers' beliefs, equal opportunities, and democracy in decision making (McLaughlin \& Talbert, 1993).

Moreover, it is important to implement training programs for mental resistance for managers and leaders of education, who acquire the necessary skills and abilities will be able to contribute to the strengthening of mental resilience (Patterson et al., 2009). We should not forget that school leadership plays an important role in transferring and accepting the vision to teachers (Ogawa \& Bossert, 1995). In addition, new teachers should be educated to strengthen their mental resistance (Pretsch et al., 2012).

Finally, it is necessary to there be a working environment at school that will lead teachers to professional satisfaction with the appropriate support of all those involved in the educational process.

\subsection{Scope of Future Research}

There is a need for any further intervention studies in this space to be conducted as trials of resilience-focused approaches based on such evidence of association (Dray, 2021). The suggested implications for research made in this conceptual analysis will aid in improving the quality of the evidence base relevant to the fostering of resilience and prevention of mental health problems at school.

\subsection{Research Limitations}

Research limitations include the small number of the sample which prevents us from making safe generalizations in the teachers' population. The research has not been conducted as a full systematic review and only examined the factors affecting the mental health of Greek teachers. It is important to be researched with a bigger number of samples in the future to have 
more reliable results concerning the mental resistance of Greek teachers. In addition, it could be investigated whether the mental resilience of Greek teachers correlates with factors related to school function such as school climate and their professional satisfaction.

\section{REFERENCES}

Bernard, B. (1995). Fostering Resilience in Children. ERIC/EECE Digest, EDO-PS-99.

Bernard, B. (2004). Resiliency: What We Have Learned. San Francisco, CA: WestEd Regional Educational Laboratory.

Cefai C. (2011). There are no losers, everyone wins: Promoting Mental Resilience in the Classroom. In From Vulnerability to Mental 97 Durability: Applications in the School Context and the Family. Volume AD (Ed.), A. Matsopoulos (pp. 301-317). Athens: Papazisis Publications,

Chadzichristou, Ch. (2011). School Psychology: Defining the role and the specialty. Athens: Typothito.

Chmitorz, A., Kunzler, A., Helmreich, I., Tüscher, O., Kalisch, R., Kubiak, T., Wessa, M., Lieb, K. (2018). Intervention studies to foster resilience - A systematic review and proposal for a resilience framework in future intervention studies. Clinical Psychology Review, 59, 78-100. https://doi.org/10.1016/j.cpr.2017.11.002

Connor, K.M., \& Davidson, J.R.T. (2003). Development of a new resilience scale: The ConnorDavidson resilience scale (CD-RISC). Depression and Anxiety, 18(2), 76-82. https://doi.org/10.1002/da.10113

Dray, J (2021). Child and Adolescent Mental Health and Resilience-Focussed Interventions: A Conceptual Analysis to Inform Future Research. Retrieved from https://doi.org/10.3390/ijerph18147315

Fenwick-Smith, A., Dahlberg, E.E. \& Thompson, S.C. (2018). A systematic review of resilience-enhancing, universal, primary school-based mental health promotion programs. BMC Psychol 6, 30. https://doi.org/10.1186/s40359-018-0242-3

Fergus, S., \& Zimmerman, M. A. (2005). Adolescent resilience: A framework for understanding healthy development in the face of risk, Annual Review of Public Health, 26, 399-419. https://doi.org/10.1146/annurev.publhealth.26.021304.144357 
Fergusson, D \& Horwood, J. (2003). Resilience to Childhood Adversity: Results of a 21-Year Study. Resilience and Vulnerability: Adaptation in the Context of Childhood Adversities. 130-155. https://doi.org/10.1017/CBO9780511615788.008

Ginsburg, K. \& Jablow, M. (2014). Building mental resilience in Children \& Adolescents - A guide for parents. Athens: Broken Hill Publishers. https://doi.org/10.1542/9781581108705

Gordon, E. W., \& Song, L. D. (1994). Variations in the experience of resilience. In M. C. Wang \& E. W. Gordon (Eds.), Educational resilience in inner-city America: Challenges and prospects (pp. 27-43). Mahwah, NJ: Lawrence Erlbaum.

Gu, Q \& Day, C. (2013). Challenges to Teacher Resilience: Conditions Count. British Educational Research Journal, 39, 22-44.

Hardy S E, Concato J and Gill T H (2004) Resilience of community-dwelling older persons, Journal of the American Geriatrics Society, 52 (2), 257-262. https://doi.org/10.1111/j.1532-5415.2004.52065.x

Henderson, N., \& Milstein, M. (2008). Schools that promote mental resilience: How it can become a reality for students and teachers. Athens: Typothito.

Higgins, G. O. (1994). Resilient adults: Overcoming a cruel past. San Francisco: Jossey-Bass.

Hornor, G. (2004). Resilience. Journal of Pediatric Health Care, 31 (3), 391-392. https://doi.org/10.1016/j.pedhc.2016.10.006

Jalongo, M.R., \& Heider, K. (2006). Editorial teacher attrition: An issue of national concern. Early Childhood Education Journal, 33 (6), 379-380. https://doi.org/10.1007/s10643$\underline{006-0122-y}$

Johnson, B., (2008). Teacher-student relationships which promote resilience at school: A microlevel analysis of students' views. British Journal of Guidance and Counseling, 36(4), 385-398. https://doi.org/10.1080/03069880802364528

Krovetz, M. (1999). Resiliency: A Key Element for Supporting Youth At-Risk. The Clearing House, 73 (2), 121-123. https://doi.org/10.1080/00098659909600163

Lundman, B., Strandberg, G., Eisemann, M., Gustafson, Y. and Brulin, C. (2007). Psychometric Properties of the Swedish Version of the Resilience Scale. Scandinavian Journal of Caring Sciences, 21(2), 229-237. https://doi.org/10.1111/j.1471-6712.2007.00461.x 
Luthar, S.S, Cicchetti, D., Becker, B. (2000). The Construct of Resilience: A Critical Evaluation and Guidelines for Future Work. Child Development. 71(3), 543-562. https://doi.org/10.1111/1467-8624.00164

Maridaki-Kassotaki A. (2013). Educational psychology. Athens: Diadrasi

Masten, A. S. \& Curtis. W. J. (2000). Integrating competence and psychopathology: Pathways toward a comprehensive science of adaptation in development. Development and Psychopathology, 12, 529-550. https://doi.org/10.1017/S095457940000314X

Masten, A.S. (2001). Ordinary magic. American Psychologist, 56 (3), 227-238. https://doi.org/10.1037/0003-066X.56.3.227

McLaughlin, M. W., \& Talbert, J. E. (2001). Professional communities and the work of high school teaching. Chicago: University of Chicago Press.

Mwangi, C. N., Ireri, A. M., Mwaniki, E. W., \& Wambugu, S. K. (2018). Relationship among Type of School, Academic Resilience and Academic Achievement among Secondary School Students in Kiambu County, Kenya. PEOPLE: International $\begin{array}{llll}\text { Journal of } & \text { Social } & \text { Sciences, } & 3(3),\end{array}$ https://doi.org/10.20319/pijss.2018.33.10921107

Netuveli, G, Wiggins, R D, Montgomery, S M, Hildon, Z, and Blane, D. (2008). Mental health and resilience at older ages: bouncing back after adversity in the British Household Panel Survey, Journal of Epidemiology and Community Health, 62 (11), 987-991. https://doi.org/10.1136/jech.2007.069138

Nygren, B, Aléx, L, Jonsén, E, Gustafson Y, Norberg, A and Lundman, B. (2005) Resilience, sense of coherence, purpose in life and self-transcendence concerning perceived physical and mental health among the oldest old, Aging \& Mental Health 9 (4), 354-362. https://doi.org/10.1080/1360500114415

Ogawa, R \& Bossert, S. (1995). Leadership as an Organizational Quality. Educational Administration Quarterly, 31, 224-243. https://doi.org/10.1177/0013161X95031002004

O'Reilly, M., Svirydzenka, N., Adams, S. (2018). Review of mental health promotion interventions in schools. Soc Psychiatry Psychiatr Epidemiol, 53, 647-662 https://doi.org/10.1007/s00127-018-1530-1 
Pearce, Jane, \& Morrison, Chad. (2011). Teacher identity and early career resilience: Exploring the links. Australian Journal of Teacher Education, 36, 47-59. https://doi.org/10.14221/ajte.2011v36n1.4

Pretsch, J., Flunger, B., Schmitt, M. (2012). Resilience predicts well-being in teachers, but not in non-teaching employees. Social Psychology of Education, 15 (3), 321-336. https://doi.org/10.1007/s11218-012-9180-8

Rutter, M. (2012). Resilience as a dynamic concept. Development and Psychopathology 24, 335-344. Psychopathology, 12, 529-550. https://doi.org/10.1017/S0954579412000028

Segal, J. (1988). Teachers have enormous power in affecting a child's self-esteem. The Brown University Child Behavior and Development Newsletter, 4, 1-3.

Siourla, E. (2018). The impact of spiritual well-being in the mental resilience of teachers. Postgraduate thesis, University of Macedonia.

Seidel D, Jagger C, Brayne C, Matthews F E, and MRC CFAS. (2009). Recovery in instrumental activities of daily living (IADLs), findings from the Medical Research Council Cognitive Function and Ageing Study (MRC CFAS), Age and Ageing 38 (6), 663-668. https://doi.org/10.1093/ageing/afp128

Spyropoulos, D.C. (2018). Cross-Cultural Entitlement and Resilience: A Suggestion for Western Cognitive Therapy. PEOPLE: International Journal of Social Sciences, 4(2), 777- 792. Retrieved from https://doi.org/10.20319/pijss.2018.42.777792

Theodosakis D. (2011). Emotional intelligence in the modern school. Athens: Grigori.

Tusaie, K., Dyer, J. (2004). Resilience: A historical review of the construct. Holistic Nursing Practice, 18(1), 3-8. https://doi.org/10.1097/00004650-200401000-00002

Zhang, M., Bai, Y \& Li, Z. (2020). Effect of Resilience on the Mental Health of Special Education Teachers: Moderating Effect of Teaching Barriers, 13, 537-544. https://doi.org/10.2147/PRBM.S257842 